\title{
The Result of a Holy Alliance: Debus and Tariqah in Banten Province
}

\author{
Rohman \\ Peneliti Bantenologi dan pengajar di IAIN Sultan Maulana \\ Hasanuddin, Banten. \\ E-mail: rohmanana@yahoo.com
}

\begin{abstract}
In this paper, the writer describes the practice of debus in Banten and its function among present-day Bantenese.

The underlying question to be considered here is the way in which debus performances are now regarded as an integral part of Banten's tradition. There is a number of studies devoted to debus in Banten and in several places in Indonesia, most of which are anthropological studies. Little attention has been given to an indepth study of debus practised by the Bantenese. In fact, debus has developed as invulnerability performance and has gone much further of late than the previous invulnerability performances in Aceh described by Snouck at the end of the nineteenth century. The writer attempts to show how the debus performances combined with aspects of tariqah' now also include several new attributes. Keywords: debus, tariqah
\end{abstract}

\section{ABSTRAK}

Dalam artikel ini penulis mendeskripsikan praktik debus di Banten dan fungsinya bagi masyarakat Banten dewasa ini.

Pertanyaan yang digarisbawahi dalam artikel ini adalah bagaimana praktik debus saat ini dianggap sebagai bagian integral dari tradisi Banten. Terdapat beberapa studi tentang Debus di Banten dan di tempat-tempat lainnya di Indonesia, yang banyak diantaranya merupakan studistudi antropologis. Sedikit sekali perhatian yang telah diberikan studi mendalam tentang debus yang diptaktikkan oleh orang-orang Banten. Faktanya, debus telah berkembang sebagai pertunjukan kekebalan dan lebih dari sekedar pertunjukan kekebalan di Aceh sebagaimana yang pernah dideskripsikan oleh Snouck pada akhir abad ke Sembilan belas. Penulis mencoba menunjukkan bagaimana praktik debus yang dikombinasikan dengan aspek-aspek tarekat saat ini agaknya memasukan banyak atribut baru.

Kata Kunci: debus, tarekat

\section{INTRODUCTION}

One of the performance arts influenced by religion is the invulnerability performance known as debus or dabus (in Banten), gedebus (in Java), daboih (in West Sumatra), rapa'i (in Aceh) or daboso (in South Sulawesi) practised in some regions of the Indonesian archipelago. There are two schools of thought regarding the origin of the term debus. ${ }^{1}$ The first indicates that debus originally developed from local tradition and that it means either tembus (penetrable) or tidak tembus (impenetrable). ${ }^{2}$ Another argument suggests that debus is an abbreviation of Dzikiran (remembrance of the word of God), Batin (spiritual) and Salawat (praising the prophet). ${ }^{3}$ The second school of thought indicates external influence in 
the formation of debus, claiming that the term is derived from the Arabic 'dabbus' meaning needle or thumbtack. ${ }^{4}$

In addition, debus can be defined either by the invulnerability performance itself or by the instruments used during the performance, as stated by Vredenbregt. According to him, the purpose of debus is to demonstrate the invulnerability of the performers by piercing their bodies with a special implement called a debus, an awl-like dagger with an iron spike at the end of a wooden hilt. ${ }^{5}$ In some regions of Banten, invulnerability performances are also known as al madad ${ }^{6}$ performances because the performers normally summon al madad before one strikes the other. During the performances, percussion instruments such as tambourines, drums, small drums (talinggit) and rattles are played and combined with dhikr, Qur'anic verses and wawacan seh (the legend of some of tariqah's founders) recitations. ${ }^{7}$ Vredenbregt conducted his fieldwork in three sub-districts of Serang, concluding that detailed descriptions of debus performances before the twentieth century do not exist. ${ }^{8}$ He added that this was not because people had not mastered the required skills but was either due to a government ban or to resistance from orthodox Islam. ${ }^{9}$

As far as Vredenbregt's argument about the lack of records of debus performances are concerned, it seems he did not consider Aceh to be an important centre for Islam in the archipelago. It is true that we cannot find any documentation of invulnerability performances in Banten before the twentieth century. Nevertheless, in describing rapa'i performances, Snouck Hurgronje implies that performances similar to debus relating to tariqahs did exist in the archipelago during the time he conducted his fieldwork. ${ }^{10}$

Snouck Hurgronje describes that rapa'i included some demonstration of invulnerability that if unsuccessful could result in sickness or death, for example, eating glass fragments, biting the heads off snakes, wounding the performers with knives and throwing the performers under horses' hooves. ${ }^{11}$ If true, this shows that debus-like performances with tariqah influence were performed in the nineteenth century and not only in Aceh but also in other places in the archipelago including Banten. Vredenbregt also found that debus performances practised in three subdistricts of Banten were influenced by Qadiriyyah tariqah, suggesting that debus as invulnerability performance is not a new phenomenon because tariqah itself was significant in the development of Islam in Banten as it was in most places in the Indonesian archipelago.

Vredenbregt's argument was strengthened by Bruinessen who pointed out that debus performances are closely related to tariqah. ${ }^{12}$ Reiterating findings related to invulnerability performances during Snouck Hurgronje's fieldwork in Aceh, Bruinessen emphasised that debus-like performances in Aceh were influenced by Rifa'iyyah tariqah. However Banten's debus was not influenced by Qadiriyyah (to be exact Qadiriyyah wa Naqshabandiyyah) alone but also by other tariqahs such as Sammaniyyah and Rifa iyyah that serve the same purpose. ${ }^{13}$ The most frequently cited explanations for the emergence of debus in Banten are first, that it was created by Mawlana Hasanuddin to attract the natives to convert to Islam and second, that Sultan Ageng Tirtayasa used it to boost his soldiers' morale during the fight against the Dutch. ${ }^{14}$ 


\section{THE TARIOAH, BANTEN SULTANATE AND THE EMERGENCE OF DEBUS}

The desire to harness the supernatural (kesakten) and master invulnerability (ilmu kebal) has been handed down from generation to generation in the archipelago. Religious influence is always evident. Before the presence of Islam for instance, people who needed protection from danger invoked magical formulae (mantera) from Hinduism or Buddhism. Meanwhile, the presence of Islam represented by tariqah gave the local inhabitants a new relationship with the supernatural and invulnerability because the dhikr and wird brought by Islamic mystics during the spread of Islam were considered more powerful than that the formulae of Hinduism or Buddhism. ${ }^{15}$ Although the purpose of tariqah is to bring performers closer to God, many native Muslims during the first phase of the spread of Islam joined tariqah orders because their rituals were similar to pre-Islamic practices. Beside the dhikr and wird considered to be like mantera, the teaching of 'uzlah (meditation) and asceticism practised by tariqah teachers were also compared to the tapa (meditation) ritual of the pre-Islamic period.

In Banten, the spread of Islam was encouraged by local rulers who worked closely with tariqah orders. According to the Sejarah Banten ${ }^{16}$ texts, sunan ${ }^{17}$ Gunung Djati and his son, Mawlana Hasanuddin (d. 1570), travelled to Mecca and Medina, the traditional centres of Islam, to obtain religious legitimacy by becoming members of a tariqah order. ${ }^{18}$ However, according to Bruinessen, some chronicles in Sejarah Banten, especially those relating to the ordination of Mawlana Hasanuddin as a member of Naqshabandiyyah and to sunan Gunung Djati joining the tariqah orders of Kubrawiyyah,
Shadziliyyah, Shattariyyah and Naqshabandiyyah, were just ancient tales designed to legitimise and strengthen the Banten dynasty's relationship with mysticism. ${ }^{19}$ He claims the Naqshabandiyyah tariqah did not exist when sunan Gunung Djati and Mawlana Hasanuddin visited the two holy cities of Islam and neither did the other tariqah orders that sunan Gunung Djati apparently joined.

Nevertheless, the founding fathers of the Banten sultanate could have joined other tariqah orders. After all, rumours of 'Abd al Qadir Jaylani's miracles (karamah) spread among Banten Muslims, proving that the Qadiriyyah tariqah's influence had existed for some time. This particular tariqah was the first tariqah in the archipelago. ${ }^{20}$ It is quite likely that sunan Gunung Djati and Mawlana Hasanuddin were members of Qadiriyyah when they preached Islam in Banten. Showing supernatural and invulnerability influenced by the 'Abd al Qadir Jaylani's miracles, They successfully converted the local Hindu and Buddhist populations by demonstrating their supernatural power and invulnerability skills. For the next two hundred years, the relationhip between tariqah teachers living in the two holy cities and the Banten rulers was much clearer.

According to Djajadiningrat, the relationship between Mecca and Banten can be observed as early as the 1630s when Banten's ruler, Abu al Mufakhir 'Abd Qadir (r.15961651) received the title of 'sultan' from the grand Sharif of Mecca. ${ }^{21}$ The sultan was so interested in Islam that he sent questions on religious matters to famous scholars in Mecca and Medina. These scholars answered Sultan 'Abd Qadir's questions. ${ }^{22}$ In addition to becoming an important link in international 
trade networks with foreign countries such as England, Denmark, China, Persia, India, Siam, Vietnam, the Philippines and Japan, Banten in the seventeenth century functioned as the home of Islamic education and a centre for the spread of Islam into the hinterland of Java and many other places in the archipelago. ${ }^{23}$

During the reign of Sultan Ageng Tirtayasa (r.1651-1682), the sultanate was influenced by Shaykh Yusuf al Makassari (d.1699), a prominent tariqah teacher from the Khalwatiyyah, Naqshabandiyyah, Shattariyyah, Qadiriyyah and Ba'alwiyyah tariqahs. ${ }^{24}$ During the confrontation with the colonial government, Shaykh Yusuf led the Banten sultanate's soldiers and his supernatural ability played a significant role in boosting his followers' morale. ${ }^{25}$ Bruinessen argued that Yusuf al Maqassari taught invulnerability skills in Banten through his tariqah teachings. ${ }^{26}$ We can assume that the presence of Yusuf Makassari with his profound knowledge of Islam and involvement with tariqahs, strengthened the interconnectivity between the tariqah, the Banten sultanate's court and invulnerability skills. Interestingly, there is no significant evidence that debus invulnerability performances which include pencak silat and music were performed in public. According to Djajadiningrat who studied the Sejarah Banten chronicles, the ruler of Banten at that time only had artistic hobbies such as raket and dedewaan and did not watch public performances of debus. ${ }^{27}$

It appears that Sultan Ageng Tirtayasa and Yusuf al Makassari only taught invulnerability skills to his soldiers to boost their morale to fight the Dutch. During this period, when tension between the Banten sultanate and the Dutch was increasing, the sultanate's officials preached Islam and taught invulnerability skills in the hinterland of Banten. This is supported by the fact that Islam had only penetrated inland regions of Banten by the late seventeenth century. ${ }^{28}$ In order to convert as many Bantenese Hindus and Buddhists as possible to the Muslim cause to support the war against the infidel Dutch, the sultanate's officials accepted the practice of local traditions, thus creating syncretism in Banten. This led to the emergence of a combination of the tariqahs dhikr and wird techniques alongside local magical formulae (jangjawokan), creating more powerful invulnerability skills to use against the Banten sultanate's enemy.

The relationship between tariqah, the Banten sultanate and invulnerability skills did not end after Sultan Ageng Tirtayasa and Yusuf al Makassari were arrested. In fact, in the second half of the eighteenth century, Sultan 'Arif Zayn al 'Ashiqin al Qadiri (r. 1753-1777) was directly involved in the genealogy of some tariqah orders after becoming the khalifah (leader) of Qadiriyah, 'Alwaniyyah and Rifa 'iyyah tariqahs. ${ }^{29}$ The sultan's full name is: al Khalifah al Sultan ibn al Sultan Abu al Nasr Muhammad 'Arifin al 'Ashiqin al Qadiri al 'Alwani al Rifa'i al Bantani alShafi' $i{ }^{30}$ The sultan's wanted to be khalifah of the Qadiriyyah and Rifa'iyyah tariqahs because of their association with shaykh 'Abd Qadir and Ahmad Rifa'i's miracles and invulnerability skills recognised by traditional Islam. ${ }^{31}$ Banten sultanate's ruler therefore seems to have developed a strong relationship with those tariqahs most involved with the supernatural and invulnerability skills. During this period, the practice of invulnerability skills based on the tariqahs teaching did not take place at court. This was to avoid raising 
Dutch suspicion that the performances might encourage increased resistance against them. On the other hand, invulnerability performances based on the tariqah's teachings was used to accelerate the spread of Islam into the hinterland of the Banten sultanate.

The explanation above leads us to presume that debus as public invulnerability performances emerged in the nineteenth century, as indicated by Snouck Hurgronje. He implied that invulnerability performances emerged as a result of competition among tariqahs to attract as many followers as possible. ${ }^{32}$ In order to compete with other tariqahs, the shaykh made his disciples increase their skill level by incorporating the shaykh's mystical prowess. From then on invulnerability games were used to persuade followers that their tariqah was more attractive than the others. Therefore, in Banten we find invulnerability performances are not only practised by the Qadiriyyah wa

Naqshabandiyyah, but also by the Sammaniyyah, Rifa'iyyah and Shadziliyyah tariqahs. Perhaps due to the peasant revolt in Banten in 1888, influenced by tariqahs' teachers, performances were forbidden by the colonial government to preserve security inof the region. Debus performances re-emerged in the twentieth century after Indonesia's independence in $1945^{33}$, now incorporating pencak silat and musical instruments.

\section{THE DEVELOPMENT OF DEBUS PERFOR- MANCE}

Unlike the debus performance as described by Vredenbreght which the show of invulnerability was conducted in pairs in which one performer stabbed his partner's body by using either the small debus (technique A) or large debus (technique B) beaten by a big wooden hammer, the debus performance after Vredenbregt's investigation produces several new invulnerability including magical games such as burning the performer's body, cooking eggs above the head of the performer, using hand to reverse the egg in the hot oil, slicing the stomach with machete, peeling the coconut, slicing the tongue by using knife, ascending the machete-ladder steps, eating the fragmented glasses and pouring the Sulfuric Acid (99h H2SO4) to the performer's body. ${ }^{34}$

According to Athoullah's investigation, other games are: Stabbing cheeks using a big pin; stabbing the neck using a sharp iron, eating hot coal' ejecting bats and snakes from the mouth; rolling on broken glass and nails; beating the head with bottles and wood; shelling coconuts with the teeth and slicing cucumbers on thestomach. ${ }^{35}$ To create a more interesting and at the same time interactive performance, the debus shaykh will invite and ask the audience to imitate the actions of debus performers by eating broken glass or brushing their hair with fire.

It is interesting to note that Vredenbregt did not refer to the invulnerability games mentioned by Hadiningrat who investigated debus in Banten in 1981, less than ten years before Vredenbregt c onducted his research. This is either because he only wanted to investigate the Qadiriyyah's influence on debus in Banten without considering local influences or perhaps the performances in the three regions he investigated really did not have any new invulnerability games and were conventional debus performances with Qadiriyyah's influence. If the latter is true, some invulnerability games in today's debus performances can be considered new ones performed as part of the show in Banten. 
New invulnerability games and magic tricks performed in debus performances demonstrate that debus has evolved from its core performance which is basically resulting from a state of trance ( fana) induced during the recitation of dhikr prescribed in tariqah teachings.

Bruinessen stated that the tariqahs' dhikr technique is only a part of debus performances and the leaders of debus performances (the debus shaykhs) are no longer strictly related to the tariqah order nor to the tariqah's genealogical tree (the silsilah). ${ }^{36}$ Some debus shaykhs practise wird in the same way the tariqahs practise dhikr and wird but none has become a khalifah of a tariqah order. Some of them are only pencak silat (traditional martial arts) teachers with a limited knowledge of dhikr and wird. According to Bruinessen, most debus teachers use magic according to the tariqahs teachings and local traditions which proves that the invulnerability techniques used in debus performances nowadays are derived from an eclectic combination of tariqah and local pre-Islamic teaching. ${ }^{37}$

\section{ELEMENTS OF DEBUS PERFORMANCE AND DEBUS FUNCTIONS \\ The debus shaykh and his functions}

The debus shaykh is the most important figure in debus. He has the authority to manage the performance because he possesses the greatest supernatural power in his group. A debus shaykh has three functions, one before, during and after the performance. Before the performance, the shaykh fulfils some obligatory rituals such as giving wird (in the context of debus this can be defined as a combination of short prayers taken from Qur'anic verses mixed with some in the local language) to his pupils to be read, memorised and recited after performing prayers five times; supervising the training of his pupils; reciting the manaqib (reading the tariqah shaykhs' supernatural stories) and preparing the holy water to protect the performers from injury and to heal their wounds. ${ }^{38}$ Vredenbregt gives five functions for a debus shaykh during the performance, namely:

1. A technical function in which he gives instructions on debus techniques to the performers.

2. As a mediator, he invokes the intercession and protection of the shaykh 'Abd al Qadir Jaylani to safeguard the performers from harm.

3. A magic function in that he renders the debus daggers as soft as the body of a woman.

4. A curative function in treating potential injuries.

5. A leadership function in the sense that the general direction of the performance is in his hands and he determines who participates. ${ }^{39}$

An additional function which Vredenbregt did not mention is the debus shaykh as Master of Ceremonies (MC), because he usually opens and closes the performance. After debus has been successfully performed, the shaykh divides up the income given to him by the official event organisers such as local government and tourist companies. He also deals with marriage proposals and circumcision ceremonies relating to participants in the performance. Besides earning money from debus performances, the shaykh is also paid by his pupils who just want to learn invulnerability skills and harness supernatural 
power without becoming debus performers.

\section{The performers}

The invulnerability performed during a debus show is not just dependent upon the debus shaykh's authority and and manaqib recitation requesting shaykh 'Abd al Qadir Jaylani or shaykh Rifa 'i's assistance to protect the performers. Indeed the performers are also required to be Muslim, be proficient in pencak silat (martial arts) and memorise wird formula provided by the shaykh. In addition, those who want to become debus performers have to endure a long and exhausting physical and mental exercise (tirakat) such as 7, 40 or 100 days of fasting according to the shaykh's order and they are obliged to eat a very small portion of cooked rice with salt and chili only when they break their fast. They also have to perform prayers five times and observe Islamic prohibitions such as stealing, drinking alcohol and committing adultery. ${ }^{40}$

It is also interesting to look at the formulae (niyyah) recited before debus performers begin fasting. Some of the incantation formulae are as follows:

Bismillamirrahmanirrahim

Niat isun puasa udu puasane wulan

Udu muasane dina muasane kakarepan isun da den karepken dening isun

Muga-muga dikabulaken dening Allah

La ilaha illa Allah Muhammad al

rasulullah $^{41}$

Another incantation formula is:

Niat kaula puasa

Muasakeun jangjawokan

Kakuatan kaulan

Bismillahirrahmanirrahim $^{42}$

If we look at these two incantations, the language used is Javanese and Sundanese Banten with additional Islamic influence such as the use of basmalah and shahadah sentences. These incantation formulae are different with the debus performers' incantation for fasting used by the Ciwasiat group in Pandeglang as follow:

Nawaytu cauma ghadin li qada'i al-hajati sunnatan lillahi ta'ala ${ }^{43}$

From the formulae above, it seems that each debus group has its own formula that must be applied before fasting to achieve invulnerability. It also shows the lack of unity among debus groups.

\section{Tawassul in tariqah and debus}

Tawassul can be defined as an individual or collective attempt to achieve gifts through a mediator (wasilah) by reciting certain surahs of the Qur'an especially surah al-Fatihah to the prophet Mumammad, the saints and khalifah in the the tariqahs' genealogy. If we examine tariqah and debus practice, similarities between the two are obvious. The main similarity is that tariqah and debus are performed by tawassul and rabitah shaykhs (the will to invoke the spirit of tariqah teachers). Athoullah however, highlighted the differences between tariqah and debus. While tariqah's shaykh emphasises the dhikr and the rabitah shaykh to guide his followers in conducting dhikr techniques as well as for spiritual experience, a debus shaykh emphasises the wird and the rabitah shaykh to gain supernatural power and invulnerability skills without strict adherence to the dhikr performance. ${ }^{44}$

In debus groups influenced by Rifa iyyah tariqah, surah al-Fatihah is offered to members of the genealogical tree. These include the prophet Muhammad, al-Khulafa' al-Rashidun, the prophet's companions (cahabah), the 
prophet's family members, tabi in and tabi'ut tabi'in, Shaykh Ahmad al Kabir al Rifa'i, Shaykh 'Abd al Qadir Jaylani, Shaykh bafi al Din Ahmad bin 'Ulwani, Shaykh Ahmad al Badawi al Rifa'i, Shaykh Ibrahim Ahmad al Dasuki, Shaykh Abu Bakr bin 'Abd Allah al Aydarus, Sultan Mawlana Hasanuddin bin Mawlana Mahdum, Sayyid Jalil, Sayyid Musa and Sayyid 'Abd al Qadir al Rifa'i, Shaykh Muhammad 'Atabah al babur, Sultan 'Arifin Zayn al 'Ashiqin al Bantani al Tsani, Sultan Abu al Mufakhir Muhammad 'Ali al Din, Shaykh Hajj Muhammad 'Arif al Rifa'i, Shaykh 'Abd Allah bin 'Abd al Qahar, Hajj Isma'il bin 'Abd al Salam and the spirit of our parents. ${ }^{45}$

In debus groups influenced by the Qadiriyyah tariqah, the surah al-Fatihah recitation is offered to the prophet Muhammad, Shaykh Muhtar al Palimbani, Shaykh Khalil Aceh and Shaykh 'Abd al Qadir Jaylani. ${ }^{46}$ However, some debus shaykhs do not merely send the surah al-Fatihah recitation to the members of the tariqah genealogy. They also offer it to the Uyut Widara Tampolong, Uyut Santika Cimahi Ujung Kulon and Embah Khaer spirits known to supernatural practitioners such as the jawara (Bantenese traditional leaders who are masters of pencak silat and possess supernatural prowess and invulnerability skills) and to pencak silat practitioners. ${ }^{47}$

\section{Genealogy and wird of debus performers}

In the tariqahs' genealogical tree, the order of teachers is clear. The recitation of the dhikr and wird is the same within a tariqah order while debus ignores genealogical chains and has many forms in the sense that debus groups can have different ways of working, using wird and incantation formulae. Debus groups with different teachers but using the same sacred formulae and activities vary considerably from place to place. A debus shaykh usually begins a debus performance by asking permission as a form of courtesy to those in the audience who also have supernatural powers, to allow them to perform debus and not to disturb the course of the performance. If the shaykh does not ask permission, undesirable incidents can happen, for example, the performers might be wounded by sharp weapons or they could become drowsy during the performance.

As for the wird texts used by the debus shaykh, they are always written in Arabic and combined with the jangjawokan, sacred formulae originating from pre-Islamic teachings usually written in old Javanese or the Sundanese language of Banten. This sacred formula is sometimes mixed with elements of surahs in the Qur'an such as al Kahf, Yusuf and al Ikhlas ${ }^{48}$ including the basmalah, hamdalah and shahadah (the Islamic profession of faith). The use of basmalah (bismillah) and hamdalah in the sacred formulae is because both have very deep Islamic influence. In Islamic teaching, the reciting of basmalah is strongly recommended by the prophet at the beginning of any act to obtain God's blessing and salvation. Likewise, recital of hamdalah is recommended after performing certain acts. The shahadah is the highest confession statement in Islam which can select who becomes a Muslim or non-Muslim.

Surprisingly, some Qur'anic verses used by debus performers in the wird to obtain invulnerability skills are confusing in terms of the text and meaning if we consult the Qur'an. The wird of debus performers from Serang for example consists of surah al Kahf and mentions:

\section{Allahu Kahfi}


Wanimafi Kahfi ${ }^{49}$

Another example is the use of part of surah al Kawthar

Bismillahirrahmanirrahim

Inna'a'tainaka 'l Kawthar

Facalli liwali

Liwali warba li wali warba

Tulung para wali sakabeh

Mangka welas mangka asih

Atine wong sedunia

Ngadeleng maring isun

La ilaha illa Allah Muhammad al Rasulullah 50

It is clear the texts above are Islamic and to some extent are also based on the Qur'an. However, after consulting the Qur'an surah al Kahf and al Kawthar not a single verse is exactly the same as the texts above. In the first formula, they are simply a combination of the name of the surah and the word Allah. The second is a combination of basmalah, the first sentence of surah al Kawthar and the jangjawokan. Indeed, in a region inhabited mostly by Muslims lacking orthodox influence but with a strong belief in mysticism, Qur'anic and Arabic texts are revered by its inhabitants who appreciate their power even though they do not understand the texts. Therefore many wirds, amulets and sacred formulae use Arabic texts derived either from just a few lines of Qur'anic text or from a sentence in Arabic combined with the local sacred formula to increase the power of the supernatural.

\section{Pencak silat (traditional martial art)}

The debus shaykh incorporates pencak silat (traditional martial art) into the invulnerability performances. This is based on the as- sumption that invulnerability skills cannot be separated from proficiency in pencak silat. In other words, those who master pencak silat would be more capable if they also possess invulnerability skills. Clearly, pencak silat is vitally important to the Bantenese because many pencak silat schools (paguron) claim their jurus (movements) were created during the time of the Banten sultanate.

All debus groups in Banten perform pencak silat, either in the opening session or in the middle of the performance when they show the duel between two pencak silat players, using sharp weapons such as a machete or a sickle. In addition, debus performers' movements during the performance are related to pencak silat movements. Due to the combination of invulnerability skills and pencak silat, many prominent pencak silat schools in Banten can also take part in debus performances. These include TTKDH (Tarikolot Tjimande Kebon Djeruk Hilir), Terumbu and Bandrong. ${ }^{51}$ In this way, the combination of invulnerability skills with pencak silat as part of Banten's heritage strengthens the importance of debus to the Bantenese. Therefore, debus performance adheres not only to Islam but also to Bantenese culture.

\section{Differences between tariqah and debus}

Besides the similarities, there are of course some differences between tariqah and debus which I attempt to illustrate in the following table 1:

Although there are differences between the two, it is in fact impossible to separate tariqah and debus because, as I noted earlier, the tariqahs requirements to recite the manaqib including sacred Islamic statements such as dhikr, wird, basmalah, shahadah and other sentences from the Qur'an are in- 
TABLE 1

COMPONENTS OF TARIQAHAND DEBUSINSTITUTIONS

\begin{tabular}{|c|c|}
\hline COMPONENTS OF TARIQAH & COMPONENTS OF DEBUS \\
\hline Allah is at the centre of proceedings. & Allah and other pre-Islamic gods are revered. \\
\hline $\begin{array}{l}\text { The aim is closeness to Allah through the mediation } \\
\text { of the shaykh. Invulnerability while in a trance is a } \\
\text { side-effect of } d h i k r \text { practice. }\end{array}$ & $\begin{array}{l}\text { The aim is to obtain invulnerability skills through } \\
\text { the shaykh's supernatural ability. }\end{array}$ \\
\hline Shaykh is part of the tariqah genealogy. & $\begin{array}{l}\text { An individual shaykh is not part of a tariqah's } \\
\text { genealogy. }\end{array}$ \\
\hline Dhikr and wird are the main teachings. & $\begin{array}{l}\text { Dhikr, wird, parts of Qur'anic verses and } \\
\text { jangjawokan sacred formulae are used. }\end{array}$ \\
\hline $\begin{array}{l}\text { Pupils can be any Muslim interested in Islamic } \\
\text { mysticism. }\end{array}$ & $\begin{array}{l}\text { Pupils are mainly Muslims from jawara groups and } \\
\text { pencak silat practitioners. }\end{array}$ \\
\hline $\begin{array}{l}\text { Fasting is based on Islamic texts e.g.such as fasting } \\
\text { in the month of ramadan month and every Sunday } \\
\text { and Thursday fasting. }\end{array}$ & $\begin{array}{l}\text { Fasting is based on Islamic texts with additional } \\
\text { obligatory fasting of a certain number of days ( } 7 \\
40 \text { or } 100 \text { days). }\end{array}$ \\
\hline $\begin{array}{l}\text { Invulnerability skills are based on genealogical chain } \\
\text { in the sense that the dhikr, niyyah and wird would } \\
\text { be the same from one teacher to another as long as } \\
\text { they are in the same tariqah and therefore tariqah } \\
\text { has a centralised leadership. }\end{array}$ & $\begin{array}{l}\text { Invulnerability skills are not based on genealogy } \\
\text { chain in the sense that the dhikr, niyyah and wird } \\
\text { are different from one teacher to another and } \\
\text { therefore debus leadership is decentralised. }\end{array}$ \\
\hline $\begin{array}{l}\text { Some tariqahs need incense (kemenyan) }{ }^{52} \text { in their } \\
\text { rituals. }\end{array}$ & $\begin{array}{l}\text { Some materials such as incense (kemenyan), } \\
\text { flower kamboja and coconut oil are obligatory. }\end{array}$ \\
\hline Pencak silat skills are not required & Pencak silat skills are required. \\
\hline
\end{tabular}

cluded in debus. The Bantenese consider debus to be part of Islamic art through which the spread of Islam takes place through the Islamic components involved in debus performances. For a number of reasons pertaining to Islam, debus has been categorised a 'white science' because those who master the invulnerability skills through debus have to ignore some Islamic prohibitions otherwise their invulnerability will be lost. This differs from black magic in that followers are not obliged to perform Islamic teachings. ${ }^{53}$ This is why debus performances are admired by the Bantenese.

\section{Debus and local politics}

The involvement of debus in local politics is something that cannot be ignored. Although it is theoretically a performance art free from political interference, debus performances are in fact used to attract the masses to vote, particularly by Golkar's ruling party in Banten as well as being a form of entertainment. The first evidence of the sigficance of debus in local politics was during Golkar's campaigns for the elections of 1971 and 1977.54 One of the Pandeglang debus groups led by Muhammad Ilyas was asked by local politicians to perform for Golkar's campaigns for those elections in Pandeglang district. ${ }^{55}$

The main factor facilitating the involvement of debus in Golkar's political campaigns is the state's coercion of debus shaykhs who are respected by debus performers and have many loyal followers. In the case of Muhammad Ilyas, besides practising debus, he was also chief of Ikatan Pencak Silat Indonesia (Indonesian Traditional Martial Arts Association, IPSI) which was affiliated to the armed forces and to the New Order. ${ }^{56}$ Another example is the debus shaykh of the Walantaka group who was directly active in politics. Besides becoming a member of Golkar at sub-district level, he was also head of the Indonesian veterans organisation in Walantaka sub-district and village leader (lurah) as well. ${ }^{57}$ As a member of Golkar, he actively participated in Golkar's work, particularly during the general election. 
This situation was strengthened by the government's initiative in 1971 to organise jawara in Banten by founding the jawara organisation known as Satkar Jawara (the Jawara Working Squad). In 1973 it became Persatuan Pendekar Persilatan Seni Budaya Banten Indonesia (the Indonesian Union of Bantenese Martial Arts, Art and Culture, PPPSBBI). The establishment of PPPSBBII which has a close relationship with Golkar, unites all the pencak silat schools in Banten most of which perform debus.

\section{Debus as Banten province's symbol and the source of income}

After the founding of Banten province, the search for a new identity intensified to distinguish it from its former province. One of the ways of reviving Banten's identity is to encourage local performance arts, most of which are influenced by Islamic culture. This influence is evident from the use of calawat, dhikr and musical instruments considered Islamic, for example, the bedug (a traditional drum made of wood) and the rebana (tambourine). In this way, debus incorporating rudat, marawis and rampak bedug become part of Banten's cultural identity. However, unlike other performance arts, debus is the most familiar because of its unique performances of invulnerability skills, bravery and power considered to be typical Bantenese characteristics.

According to information obtained from Banten province's Culture and Tourism Bureau, there are 26 active debus groups spread across five regions, namely Lebak (5), Pandeglang (8), Serang district (2), Serang municipality (7) and Cilegon municipality (4) ${ }^{58}$ However, the number of groups could be higher because some are not recognised, either because local government failed to register them or because the groups themselves do not want to be registered, to protect the secrets behind their invulnerability practices. Missing from the official list are debus groups such as Taman Jaya in Ujung Kulon and the Ciwasiat group, both from Pandeglang district, as well as groups from Cikande, Ciruas, Taktakan and Cikeusal, where Vredenbregt and Hadiningrat conducted their fieldwork in the 1970s and 1980s.

The way debus operates nowadays has changed in two ways. First, invulnerability performances now take place in many cities, in Indonesia and abroad as well as in Banten. Second, because some debus groups perform for tourists, the performers are no longer just farmers filling their spare time after the harvest but are now semi-professional performers who depend on debus to support their families financially. According to $\mathrm{Tb}$. Ence, Banten province's Culture and Tourism Bureau normally gives a debus group between 3 and 7 million rupiah for a performance lasting between one and one-and-ahalf hours depending on the distance between the debus group's home base and the location of the performance. ${ }^{59}$ The amount of money they obtain could be three to four times higher if they are invited to perform in other provinces such as Jakarta and Bali or countries like Japan, Singapore, France and the Netherlands.

To ensure debus groups survive and develop, local government has implemented programmes to provide musical equipment, to invite them to perform at official ceremonies held by Banten province's administration, to help them work with privatelyowned TV stations and to promote debus on 
the Banten province's official website. ${ }^{60}$

Moreover, to preserve debus performance as part of Banten province's heritage, the local government plans to register the patent for Banten's debus. ${ }^{61}$

\section{CONCLUSION}

In this chapter, I have shown that debus has existed alongside the spread of Islam in Banten and cannot be separated from the tariqah orders that introduced invulnerability skills to the sultanate of Banten. The combination of invulnerability skills and Islamic ritual has led to debus performances becoming part of Bantenese tradition. The emergence of debus as public performance is also a result of the reconciliation between Islam and pre-Islamic beliefs. A number of Islamic elements from tariqah teachings and preIslamic components have been combined to produce the invulnerability performances we see today performed in public. In this sense, debus performance can be regarded as the result of a 'holy alliance' between Islam and local pre-Islamic beliefs. Furthermore, debus has become one of Banten province's symbols and icons, particularly after Banten became Indonesia's thirtieth province.

\section{ENDNOTES}

Some of the more recent studies on debus are: Ayatullah Khumaeni. "The Phenomenon of Magic in Banten", Unpublished MA Thesis Leiden University; Atho'ullah et al.. 2004. Laporan Hasil Penelitian Debus di Masyarakat Banten. Unpublished Research. Serang. MUI Provinsi Banten; Masruri, Teknik Magis Atraksi Debus: Sejarah Debus dan Mengungkap Teknik Atraksinya (Solo: C.V. Aneka, 1998); Nasution, Isman P..Debus, Islam dan Kyai. Unpublished MA thesis. University of Indonesia; Martin van Bruinessen, Kitab Kuning, Pesantren, dan Tarekat: Tradisi-Tradisi Islam di Indonesia. (Bandung: Mizan, 1995.); Imron Arifin, Dabus: Ilmu Kekebalan dan Kesaktian dalam Tarekat Rifa'iyah (Malang: Kalimasahada Press, 1993); Margaret J. Kartomi, Margaret J., 'Dabuih in West Sumatra: A
Synthesis of Muslim and Pre-Muslim Ceremony and Musical Style', in Archipel Vol. 41 (1991); Hadiningrat, K.., Kesenian Tradisional Debus. (Jakarta: Departemen Pendidikan dan Kebudayaan, 1981); Erman Makmur et al., "Permainan Dabus di Minangkabau," Padang: Proyek Pengembangan Permuseuman Sumbar; 1981)

Vredenbregt, J. 'Dabus in West Java', in Bijdragen tot de Taal-, Land- en Volkenkunde. (Leiden KITLV, 1973).

2 K. Hadiningrat, Kesenian Tradisional Debus, p.11.

3 Masruri, Teknik Magis, p.16.

4 Atjeh, Aboebakar. 1985. Pengantar Ilmu Tarekat: Uraian Tentang Mistik. Solo: Ramadhani. p.357.

5 Vredenbregt, Dabus in West Java, p.302.

6 Al Madad is probably the name of the shaykh of the al Qadiriyyah tariqah who came to Banten to teach the invulnerability science. See Nitibaskara, Ronny. 1993. Reaksi Sosial Terhadap Tersangka Dukun Teluh di Pedesaan Banten Jawa Barat 1985-1990: Studi Kasus Desa S dan A Kecamatan Sajira dan Bojonegara. Ph.D Dissertation. University of Indonesia. p.155.

7 Tarekat/tariqah is derived from the Arabic tariga meaning path, way or method. In this context, it has two meanings. First, it is a combination of spiritual techniques and devotional practices employing the dhikr (remembering God) formula "la ilaha illa Allah" in a specific way for a given number of times. It includes several prayer formulae such as hizb and calawat (praising a prophet) and litanies. These recitations involve breath control and particular body movements. One can only receive instruction in these practices from a tariqah teacher. See Martin van Bruinessen, Shari'ah Court, Tariqah and Pesantren: Religious Institutions in the Banten Sultanate', in Archipel Vol. 50. (1995), p. 177. The second meaning refers to the group influenced by prominent mystic teachers such as 'Abd al Oadir al Jaylani for the Oadiriyyah tariqah.

8 Martin van Bruinessen, Shariah Court, p.303.

9 Martin van Bruinessen, Shariah Court, p.303.

10 Snouck Hurgronje conducted his research on Aceh in July 1891. See Snouck Hurgronje, C.. 1906. The Achehnese Volume I. Leiden: Brill. p.v.

11 C. Snouck Hurgronje, The Achehnese. Vol. II. (Leiden: Brill, 1906), pp.249-257.

12 Martin van Bruinessen, Shariah Court, p.220.

13 Martin van Bruinessen, Shariah Court, p.221.

14 K. Hadiningrat, Kesenian Tradisional Debus. pp.10-11; Ronny, Nitibaskara, Reaksi Sosial. pp.155-156.

15 Vincent J.H Houben. 2003.'Southeast Asia and Islam'., in Annals of the American Academy of Political and Social Science. Vol. 588. p.157; Widjojoatmodjo, Raden Abdulkadir. 1942. 'Islam in the Netherlands East Indies', in The Far Eastern Quarterly. Vol. 2, No. 1. p.50; Martin van Bruinessen, Shariah Court, p.221.

16 Sejarah Banten is a series of dynastic chronicles about Banten first composed in 1662 and 1663; the oldest 
edition still in existence dates from 1732. See Pudjiastuti, Titik. 2000. Sejarah Banten: Suntingan Teks dan Terjemahan Disertai Tinjauan Aksara dan Amanat. Ph.D dissertation. p.13.

17 Sunan is a sacred title in Java for those who perform miracles (karamah). See Hosein Djajadiningrat, Hosein. 1983. Tinjauan Kritis tentang Sejarah Banten Jakarta: Djembatan. p.138.

18 Martin van Bruinessen. Shari'ah Court, pp.265-267.

19 Martin van Bruinessen. Shari'ah Court, pp.265-267.

20 Martin van Bruinessen. 'Tarekat Oadiriyah dan Ilmu Syeikh Abdul Qadir Jilani di India, Kurdistan, dan Indonesia', in Jurnal Ulumul Quran Vol. 1. (1989), p.69. The first follower of Qadiriyyah in the archipelago was Samzah al Fancuri (d. 1590).

21 Hosein Djajadiningrat. Tinjauan Kritis. p.196.

22 Azyumardi Azra. The Origin of Islamic Reformism to Indonesia: Networks of Middle Eastern and MalayIndonesian Ulama in the Seventeenth and Eighteenth Centuries (Hawai'l: University of Hawai'i Press 2004), pp.88-89.

23 Azyumardi Azra. The Origin of Islamic Reformism. p.95.

24 Martin van Bruinessen. Shari'ah Court. p.268.

25 Martin van Bruinessen. Tarekat Naqsabandiyah di Indonesia. (Mizan: Bandung 1992), p.35. See also Abu Hamid, Shaykh Yusuf: Seorang Ulama, Sufi dan Pejuang. (Jakarta: Yayasan Obor Indonesia, 1994), p. 99.

26 Martin van Bruinessen. Kitab Kuning, p.221.

27 According to Djajadiningrat, raket is the Bantenese term for the wayang wong (male puppets) performance art. He could not explain the meaning of dedewaan. Hosein Djajadiningrat. Tinjauan Kritis. p.58.

28 Ota Atsusi. 'Orthodoxy and Reconciliation: Islamic Strategies in the Kingdom of Banten, C. 1520-1813', in Atsusi, Ota et al (eds). Islam in Contention: Rethinking Islam and State in Indonesia (Jakarta: The Wahid Institute, 2010), p.409.

29 Julian Millie. Splashed by the Saint: Ritual Reading and Islamic Sanctity in West Java (Leiden: KITLV Press, 2009), p.23.

30 Julian Millie. Splashed by the Saint, p.23.

31 C. Snouck Hurgronje, The Achehnese. p.249. See also Martin van Bruinessen, 'Shaykh 'Abd al Oadir and the Oadiriyyah in Indonesia', in Journal of the History of Sufism Vol. 1-2. (2000), pp.361-395.

32 C. Snouck Hurgronje, The Achehnese. p.217 and C. Snouck Hurgronje, in Vrendenbregt. Dabus in West Java. pp.304-305.

33 J. Vredenbregt. Dabus in West Java. p.303.

34 K. Hadiningrat, Kesenian Tradisional Debus, pp.64-65.

35 Athoullah, Laporan Hasil Penelitian Debus di Masyarakat Banten. pp. 64-65. In 2009, when I accompanied some Japanese students conducting fieldwork in Ujung Kulon, the village chief invited a local debus group who rolled on thorns, ejected bats from peeled coconuts, made men's genitals disappear for a while and made coconut milk turn red after it was cut in half.

36 Martin van Bruinessen. Kitab Kuning. p.278. See also C. Snouck Hurgronje, Dabus in West Java. p.252.

37 C. Snouck Hurgronje, Dabus in West Java. p.252.

38 Most of manaqib recitation nowadays are not recited in the beginning of debus performance because the audience feel bored and therefore the shaykh conducted manaqib recitation in his house some days before the performance. See, Athoullah, Laporan Hasil Penelitian Debus di Masyarakat Banten, p. 56. This is also to note that the mediatory function of debus shaykh can be conducted before or during the performance.

39 J. Vredenbregt, Dabus in West Java, pp. 307-308.

40 J. Vredenbregt, Dabus in West Java, p.306. Isman, Debus, Islam dan Kyai, p.136.

41 Athoullah, Laporan Hasil Penelitian Debus, p.49. Athoullah did not name the debus group practising this incantation but I think this formula is used by debus groups in Serang because they use Javanese Banten language. I would translate this formula as follows: In the name of Allah the most gracious and the most merciful, I intend to fasting not for the sake of the moon, not for the sake of the day or for the sake of myself, I have some desires, I hope that Allah will agree, no God except Allah and Muhammad is his messenger.

42 Athoullah, Laporan Hasil Penelitian Debus, p.49. This is probably the incantation formula used by a debus group in southern Banten because it is in the Sundanese Banten language. I translate it as follows: I intend to fast, the fasting is for jangjawokan, give me power, in the name of Allah the most gracious and the most merciful.

43 Interview with NA, a debus performer from the Ciwasiat debus group of Pandeglang on $11^{\text {th }}$ April 2011. The incantation is in Arabic. My translation of it is as follows: I intend to fast tomorrow in order that Allah will grant my wish (to be invulnerable).

44 Athoullah. Laporan Hasil Penelitian Debus, p.52.

45 Athoullah. Laporan Hasil Penelitian Debus, p.52

46 J. Vredenbregt, Dabus in West Java, p.308.

47 Athoullah, Laporan Hasil Penelitian Debus, p.52. He also emphasised that debus performers do not necessarily want to study tariqah teachings, they just want to master invulnerability skills. This is true of the jawara group.

48 Isman, Debus, Islam dan Kyai, p.97.

49 Isman, Debus, Islam dan Kyai, p.98.

50 Athoullah. Laporan Hasil Penelitian Debus, pp.59-60.

51 See the table of debus groups in Banten in my appendix.

52 Interview with K.H. Munfassir, leader of the Padarincang pesantren on $12^{\text {th }}$ March 2011 
53 Isman, Debus, Islam dan Kyai, p.138.

54 See http://majalah.tempointeraktif.com/id/arsip/ 1980/06/07/SD/mbm.19800607.SD53553.id.html. Accessed on $18^{\text {th }}$ April 2011.

55 http://majalah.tempointeraktif.com/id/arsip/1980/06/ 07/SD/mbm.19800607.SD53553.id.html. Accessed on $18^{\text {th }}$ April 2011.

56 See 'How the New Order co-opted Indonesian Traditional Martial Arts Association (IPSI)', in DouglasWilson, Ian. 2002. The Politics of Inner Power: The Practice of Pencak Silat in West Java. Ph.D dissertation. Murdoch University. p.211.

57 Isman, Debus, Islam dan Kyai, p.147.

58 I received information from Tb. Ence Fahrurozi, head of the Programme, Evaluation and Report Division of the Culture and Tourism Bureau in Banten province in an email entitled 'Daftar Sanggar Debus se-Banten' on $12^{\text {th }}$ April 2011. According to him, in 2008 the bureau started to register debus groups in Banten and this information is verified annually. However, according to Ranta Suharta, the previous head of the Culture and Tourism Bureau in Banten province, there were 39 debus groups in Banten. See http:// www.antaranews.com/berita/1251465904/senidebus-banten-segera-dipatenkan. Accessed on $17^{\text {th }}$ April 2011.

59 Interview with Tb. Ence F. on 19 $9^{\text {th }}$ April 2011.

60 Interview with Tb. Ence F. on $19^{\text {th }}$ April 2011.

61 See http://oase.kompas.com/read/2009/08/29/ $01424479 /$

takut.diklaim.pihak.lain.debus.banten.dipatenkan. Accessed on $19^{\text {th }}$ April 2011.

\section{BIBLIOGRAPHY}

Arifin, Imron. 1993. Dabus: Ilmu Kekebalan dan Kesaktian dalam Tarekat Rifa'iyah. Malang: Kalimasahada Press.

Atjeh, Aboebakar. 1985. Pengantar Ilmu Tarekat: Uraian Tentang Mistik. Solo: Ramadhani.

Atsusi, Ota. 2010. 'Orthodoxy and Reconciliation: Islamic Strategies in the Kingdom of Banten, C. 1520-1813', in Atsusi, Ota et al (eds). Islam in Contention: Rethinking Islam and State in Indonesia. Jakarta: The Wahid Institute.

Atho'ullah et al.. 2004. Laporan Hasil Penelitian Debus di Masyarakat Banten. Unpublished research. Serang. MUI Provinsi Banten.

Azra, Azyumardi. 2004. The Origin of Islamic Reformism to Indonesia: Networks of Middle Eastern and MalayIndonesian Ulama in the Seventeenth and Eighteenth Centuries. Hawa'i: University of Hawai'i Press.

Djajadiningrat, Hosein. 1983. Tinjauan Kritis tentang Sejarah Banten Jakarta: Djembatan.

Douglas-Wilson, Ian. 2002. The Politics of Inner Power: The Practice of Pencak Silat in West Java. Ph.D dissertation. Murdoch University.
Hadiningrat, K.. 1981. Kesenian Tradisional Debus. Jakarta: Departemen Pendidikan dan Kebudayaan.

Hamid, Abu. 1994. Shaykh Yusuf: Seorang Ulama, Sufi dan Pejuang. Jakarta: Yayasan Obor Indonesia.

Houben,Vincent J.H.. 2003.'Southeast Asia and Islam'., in Annals of the American Academy of Political and Social Science. Vol. 588.

Khumaeni, Ayatullah. 2009. The Phenomenon of Magic in Banten Unpublished MA Thesis Leiden University.

Makmur, Erman et al.. 1981. Permainan Dabus di Minangkabau, Proyek Pengembangan Permuseuman Sumbar

Margaret J. Kartomi, Margaret J.. 1991. 'Dabuih in West Sumatra: A Synthesis of Muslim and Pre-Muslim Ceremony and Musical Style', in Archipel Vol. 41

Masruri 1998. Teknik Magis Atraksi Debus: Sejarah Debus dan Mengungkap Teknik Atraksinya. Solo: C.V. Aneka.

Millie, Julian. 2009. Splashed by the Saint: Ritual Reading and Islamic Sanctity in West Java. Leiden: KITLV Press.

Nasution, Isman P. 2002. Debus, Islam dan Kyai. Unpublished MA thesis. University of Indonesia.

Nitibaskara, Ronny. 1993. Reaksi Sosial Terhadap Tersangka Dukun Teluh di Pedesaan Banten Jawa Barat 1985-1990: Studi Kasus Desa S dan A Kecamatan Sajira dan Bojonegara. PhD Dissertation. University of Indonesia.

Pudjiastuti, Titik. 2000. Sejarah Banten: Suntingan Teks dan Terjemahan Disertai Tinjauan Aksara dan Amanat. Ph.D dissertation.

Van Bruinessen, Martin. 1989. 'Tarekat Qadiriyah dan Ilmu Syeikh Abdul Oadir Jilani di India, Kurdistan, dan Indonesia', in Jurnal Ulumul Quran Vol. 1. 1992. Tarekat Naqsabandiyah di Indonesia. Mizan: Bandung. 1995. Kitab Kuning, Pesantren, dan Tarekat: TradisiTradisi Islam di Indonesia. Bandung: Mizan. 2000. 'Shaykh 'Abd al Oadir and the Oadiriyyah in Indonesia', in Journal of the History of Sufism Vol. 1-2.

Vredenbregt, J.. 1973. 'Dabus in West Java', in Bijdragen tot de Taal-, Land-en Volkenkunde. KITLV.

Widjojoatmodjo, Raden Abdulkadir. 1942. 'Islam in the Netherlands East Indies', in The Far Eastern Quarterly. Vol. 2, No. 1.

Snouck Hurgronje, C.. 1906. The Achehnese. Vol. II. Leiden: Brill.

Internet sources

http://oase.kompas.com/read/2009/08/29/01424479/ takut.diklaim.pihak.lain.debus.banten.dipatenkan. Accessed on $19^{\text {th }}$ April 2011.

http://www.antaranews.com/berita/1251465904/senidebus-banten-segera-dipatenkan. Accessed on $17^{\text {th }}$ April 2011.

http://majalah.tempointeraktif.com/id/arsip/1980/06/07/ SD/mbm.19800607.SD53553.id.html. Accessed on 
$18^{\text {th }}$ April 2011

Interview

Interview with Tb. Ence F. on 19 ${ }^{\text {th }}$ April 2011.

Interview with K.H. Munfassir, leader of the Padarincang pesantren on $12^{\text {th }}$ March 2011.

Interview with NA, a debus performer from the Ciwasiat debus group of Pandeglang on $11^{\text {th }}$ April 2011. 